\title{
KARAKTERISTIK DAKTILITAS SS304 YANG TEROKSIDASI PADA TEMPERATUR TINGGI
}

\author{
Jan Setiawan, Sungkono \\ Pusat Teknologi Bahan Bakar Nuklir - BATAN \\ Kawasan Puspiptek Serpong Gd.20, Tangerang Selatan, Banten 15314 \\ e-mail: jansetiawan@batan.go.id \\ (Naskah diterima: 08-09-2017, Naskah direvisi: 10-10-2017, Naskah Disetujui: 27-10-2017)
}

\begin{abstract}
ABSTRAK
KARAKTERISTIK DAKTILITAS SS304 YANG TEROKSIDASI PADA TEMPERATUR TINGGI. Perubahan karakteristik kekerasan, kekuatan tarik dan daktilitas SS304 yang dikenai perlakuan panas pada temperatur tinggi dengan media udara telah dilakukan. Baja SS304 merupakan baja tahan karat yang memiliki berbagai keunggulan sehingga banyak digunakan di dunia industri. Pada penelitian ini digunakan sampel uji dari pipa SS304 dengan diameter $30 \mathrm{~mm}$ dipotong secara transversal sehingga berbentuk cincin dengan lebar $3 \mathrm{~mm}$. Sampel dikenai proses oksidasi dengan pemanasan pada temperatur $600^{\circ} \mathrm{C}, 800^{\circ} \mathrm{C}$ dan $1000^{\circ} \mathrm{C}$ selama 1 dan $2 \mathrm{jam}$ di dalam media udara. Setelah proses oksidasi sampel dikenai pendinginan baik secara alamiah diluar tungku atau dipercepat menggunakan media air, kemudian dilakukan pengujian kekerasan dan kekuatan tarik kearah transversal. Hasil pengujian menunjukkan bahwa terjadi peningkatan kekerasan pada sampel SS304 yang dikenai pendinginan dipercepat dibandingkan dengan sampel SS304 yang dikenai pendinginan alamiah. Nilai kekerasan tertinggi diperoleh pada pemanasan $1000^{\circ} \mathrm{C}$ selama 1 jam dengan pendinginan dipercepat. Perubahan nilai kekerasan sebelum dan setelah melalui proses perlakuan terjadi dari 281,25 HV menjadi $468 \mathrm{HV}$. Nilai kekuatan tarik sampel SS304 memiliki kecenderungan menurun, namun daktilitasnya mengalami peningkatan. Hasil uji menunjukkan adanya penigkatan kekuatan tarik dan daktilitas SS304 yang diberi perlakuan pemanasan pada temperatur $600{ }^{\circ} \mathrm{C}$ selama 2 jam dan dikenai pendinginan alamiah. Kekuatan tariknya menjadi 744,04 MPa dan elongasinya meningkat sebesar $12,38 \%$. Dari hasil pengujian diperoleh suatu pedoman bahwa penggunaan SS304 dalam lingkungan oksidasi pada temperatur tinggi dibatasi maksimum di temperatur $600^{\circ} \mathrm{C}$.
\end{abstract}

Kata kunci: daktilitas, SS304, oksidasi, temperatur tinggi. 


\begin{abstract}
DUCTILITY CHARACTERISTIC OF HIGH-TEMPERATURE OXIDIZED SS304. This paper shows changes in hardness, tensile strength and ductility characteristics of SS304. The SS304 was processed by heat treatment at high temperature in atmospheric environment. SS304 is a type of stainless steel with many superior properties used in industry. In this research, a pipe made of SS304 with $30 \mathrm{~mm}$ in diameter was cut in transversal direction at $3 \mathrm{~mm}$ width to be used as a sample. The sampleswereprocessed by heat treatment at 600,800 and $1000{ }^{\circ} \mathrm{C}$ for 1 and 2 hours in atmospheric environment. After the oxidation process, the samples were cooledby natural cooling outside the furnace or quenched in water. Hardness testing and ring tensile testing were done to the high-temperature oxidized SS304. Analyses were done to study changes in hardness, tensile strength and ductility characteristics of SS304 after oxidation process. The results show that hardness escalation occurs mainly for samples that were cooled by quenching in water compared to natural cooling. The highest hardness value was observed for the sample oxidized at $1000{ }^{\circ} \mathrm{C}$ for 1 hour and cooled by quenching, where hardness value changed from 281,25 HV before oxidation to $468,00 \mathrm{HV}$ after oxidation. The tensile strength of the samples, however, tend to decrease, whilethe ductility of some samples tend to increase. Increase in tensile strength followed by increase in ductility occursfor samplesoxidized at $600{ }^{\circ} \mathrm{C}$ for 2 hours with natural cooling. The tensile strength after oxidation reaches a value of 744,04 MPa with $12,38 \%$ elongation escalation. As a guidance for implementation, SS304 in high temperature oxidation environment should be limited by temperature of $600^{\circ} \mathrm{C}$.
\end{abstract}

Keywords: ductility, SS304, oxidation, high temperature. 


\section{PENDAHULUAN}

Dunia industri kimia, perminyakan, pembangkit listrik dan nuklir pada umumnya menggunakan pipa stainless steel (SS=baja tahan karat) sebagai penyalur fluida (cairan ataupun gas) baik dalam kondisi dingin ataupun panas[1]. Ketika bahan dikenai pemanasan pada temperatur tinggi akan mengalami perubahan struktur kristal dan diikuti perubahan karakteristik mekaniknya. Secara umum baja tahan karat memiliki karakteristik laju pengerasan, daktilitas, kekuatan, kekerasan, ketahanan panas, ketahanan korosi ketangguhan kriogenik yang tinggi dibandingkan dengan baja karbon sedang, Khusus untuk baja tahan karat austenit memiliki karakteristik respon terhadap magnet yang rendah. Dalam industri nuklir baja tahan karat merupakan kandidat untuk digunakan kelongsong bahan bakar Supercritical Water-cooled Reactor (SCWR) dan Lead-cooled Reactor (LFR) hingga temperaturnya mencapai $600{ }^{\circ} \mathrm{C}$ [2].

SS304 merupakan baja tahan karat austenit dengan spesifikasi dasar umumnya mengandung paling sedikit $16 \% \mathrm{krom}(\mathrm{Cr})$ dan $6 \%$ nikel (Ni) [3]. Dalam usaha untuk meningkatkan karakteristik baja tahan karat untuk dapat digunakan bahan struktur dan ditempatkan pada lingkungan tertentu diperlukan beberapa keunggulan terhadap mekanik sehingga perlu ditambahkan unsurunsur pemadu seperti Mo, Ti, Cu. Komposisi kimia dari SS304 secara umum ditunjukkan pada Tabel 1.

Tabel 1. Komposisi kimia SS304 [3,4].

\begin{tabular}{|c|c|c|}
\hline Unsur & $\begin{array}{c}\text { Minimum } \\
\text { (\% berat) }\end{array}$ & $\begin{array}{c}\text { Maksimal } \\
\text { (\% berat) }\end{array}$ \\
\hline $\mathrm{C}$ & 0,08 & 0,08 \\
\hline $\mathrm{Si}$ & 1,00 & 1,00 \\
\hline $\mathrm{Mn}$ & 2,00 & 2,02 \\
\hline $\mathrm{Ni}$ & 8,00 & 10,50 \\
\hline $\mathrm{Cr}$ & 18,00 & 20,00 \\
\hline
\end{tabular}

Dalam pembuatan baja tahan karat, proses solidifikasi dapat dilakukan melalui beberapa mekanisme antara lain (1) mode $A$ atau feritik ( $L \rightarrow L+\delta \rightarrow \delta)$; (2) mode $B$ atau feritik-austenit $(\mathrm{L} \rightarrow \mathrm{L}+\delta \rightarrow \mathrm{L}+\delta+\mathrm{Y} \rightarrow \mathrm{y}+$ $\delta$ ); (3) mode $C$ atau austenit-feritik ( $\mathrm{L} \rightarrow \mathrm{L}+$ $\mathrm{Y} \rightarrow \mathrm{L}+\mathrm{Y}+\delta \rightarrow \mathrm{Y}+\delta$ ); dan (4) mode $\mathrm{D}$ atau austenit $(\mathrm{L} \rightarrow \mathrm{L}+\mathrm{Y} \rightarrow \mathrm{Y})$. Mode ini dapat diprediksi dengan baik menggunakan rasio ekivalen antara $\mathrm{Cr}$ dan $\mathrm{Ni}[3]$. Pada umumnya selama mengalami proses solidifikasi baja tahan karat austenit mengandung fasa $\delta$ ferit[3]. Nilai ultimate tensile strength (UTS; kekuatan tarik) sebesar $505 \mathrm{MPa}$ [4]. dan nilai yield strength (YS; kekuatan luluh) berkisar antara 150-300 MPa[5].

Baja tahan karat austenit memiliki matriks larutan padat dengan energi salah tumpuk yang rendah. Pada Gambar 1 disajikan diagram fasa Temperature Time Transformation (TTT) yang menunjukkan perubahan fasa ketika baja tahan karat mendapat perlakukan panas.

Perlakuan panas pada baja tahan karat dilakukan dengan tujuan untuk memperoleh karakteristik mekanik tertentu sesuai dengan kebutuhan penggunaannya. Ada beberapa perlakuan panas yang penting antara lain [4]:

(1) Pemulihan tegangan yang dilakukan pada temperatur rendah untuk menghilangkan tegangan internal yang tersisa setelah proses pencetakan.

(2) Proses anil dilakukan untuk dapat meningkatkan keuletan maupun ketangguhan serta dapat mengurangi kekerasan dan menghilangkan fasa karbida. Pemanasan sampel hingga temperatur $950{ }^{\circ} \mathrm{C}$ kemudian ditahan selam 2 jam. Proses pendinginan dilakukan di dalam tungku dan sampel dikeluarkan setelah temperatur di dalam tungku mencapai temperatur kamar.

(3) Proses normalisasi dilakukan untuk meningkatkan kekuatan dengan keuletan tertentu. Pemanasan sampel dilakukan pada temperatur $950{ }^{\circ} \mathrm{C}$ 
dengan waktu penahanan selama 2 jam.

Seletah waktu pemanasan tercapai, sampel dikeluarkan dan didinginkan secara alamiah hingga temperatur kamar.

(4) Proses pengerasan dan penemperan dilakukan untuk meningkatkan kekerasan atau ketangguhan. Proses pengerasan dapat dilakukan dengan pendinginan cepat. Proses ini dilakukan dengan memanaskan sampel pada temperatur $950 \quad{ }^{\circ} \mathrm{C}$ selama 2 jam. Setelah waktu tercapai, sampel di celupkan ke dalam media pendingin seperti air, pasir atau oli selama 30 menit, sedangkan proses penemperan sampel dipanaskan pada temperatur $950{ }^{\circ} \mathrm{C}$ selama 2 jam. Penemperan dilakukan pemanasan kembali pada temperatur yang lebih rendah dan waktu yang bervariasi untuk memperoleh karakteristik tertentu.

(5) Proses austempering dilakukan untuk memperoleh fasa bainit yang memiliki kekuatan tinggi dengan daktilitas dan ketahanan aus yang baik. Pengerasan permukaan pada daerah tertentu dapat dilakukan menggunakan induksi, plasma atau laser.

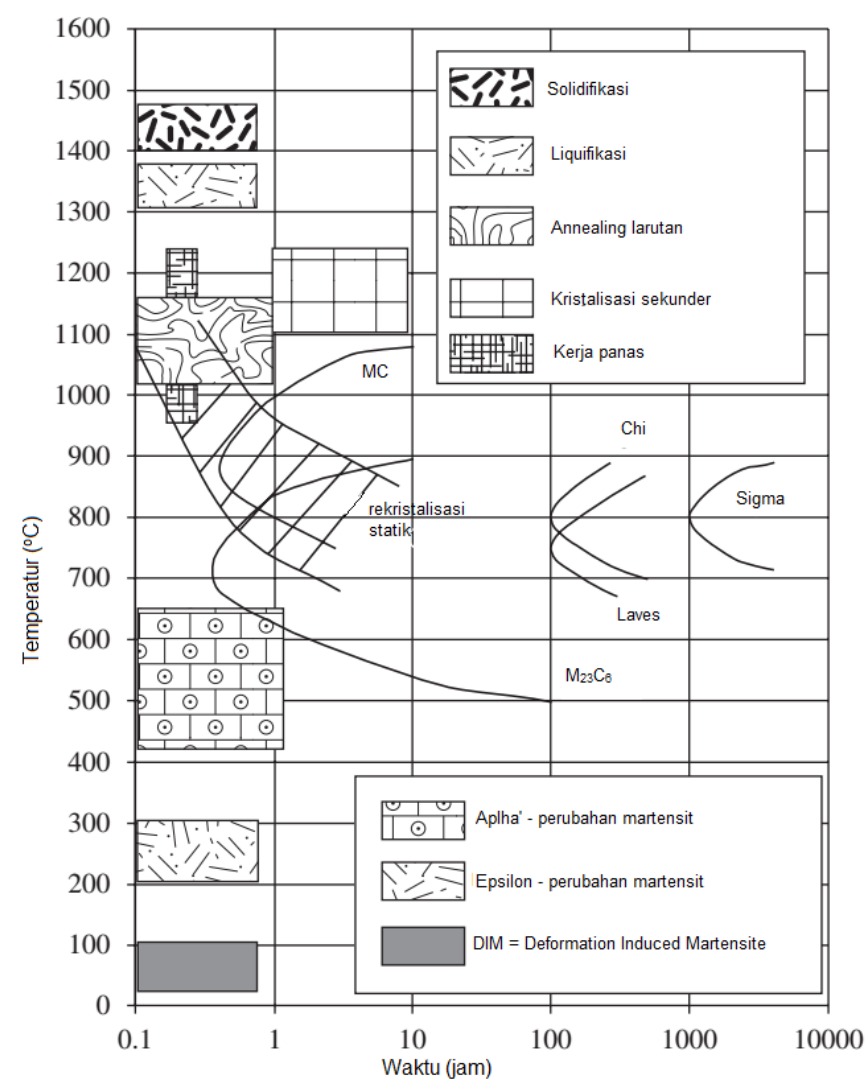

Gambar 1. Transformasi fasa pada baja tahan karat austenit [3].

Beberapa fasa presipitat yang dapat terjadi pada saat perlakuan panas seperti yang ditunjukkan pada Gambar 1[6].

(1) Fasa $\mathrm{M}_{23} \mathrm{C}_{6}$ merupakan fasa karbida dengan struktur FCC, umumnya mengandung $\mathrm{Cr}$ sebagai unsur logam utama, sedangkan $\mathrm{Ni}$, Mo dan $\mathrm{Fe}$ adalah unsur pensubstitusinya. Nukleasi fasa ini mudah terjadi pada saat 30 menit pertama ketika pemanasan dilakukan pada temperatur $750{ }^{\circ} \mathrm{C}$. Keberadaan fasa ini dapat diamati dengan adanya twin boundaries dan intergranular pada batas butir. 
(2) Fasa $\sigma$ merupakan fasa intermetalik dengan struktur tetragonal yang umumnya mengandung $\mathrm{Cr}$ dan Mo. Fasa ini muncul setelah 100 jam pemanasan pada temperatur $700{ }^{\circ} \mathrm{C}$. Fasa ini dapat ditemukan pada batas butir, twin boundaries dan intergranular.

(3) Fasa Laves memiliki struktur heksagonal, umumnya mengandung $\mathrm{Fe}$ dan Mo. Presipitatnya yang berada pada intergranular, dan terbentuk setelah pemanasan dilakukan selama 1000 jam pada temperatur $600{ }^{\circ} \mathrm{C}$ dan $800^{\circ} \mathrm{C}$.

(4) Fasa-fasa lain yang mungkin muncul sebagai presipitat seperti fasa $G$ yang merupakan fasa silisida, kemudian fasa $\mathrm{NbC}, \mathrm{NbN}, \mathrm{TiC}$ dan $\mathrm{TiN}$ yang memiliki struktur FCC.

Pengujian tarik merupakan salah satu pengujian yang penting dilakukan untuk memberikan informasi mengenai kekuatan bahan dalam perancangan produk atau pembuatan struktur. Dalam penelitian ini dilakukan pengkondisian terhadap sampel pipa SS-304 pada temperatur kerja $600{ }^{\circ} \mathrm{C}$, $800{ }^{\circ} \mathrm{C}$ dan $1000{ }^{\circ} \mathrm{C}$ dalam suasana udara (oksidasi) selama 1 dan 2 jam, kemudian mengalami pendinginan alamiah dengan media udara dan dipercepat dengan menggunakan air. Pendinginan alamiah yang dimaksud adalah pendinginan diluar tungku berhuhungan langsung dengan udara sampai mencapai temperatur kamar. Pengamatan yang dilakukan terhadap sampel uji adalah perubahan kekerasan, daktilitas dan kekuatan tariknya. Penekanan pengujian tarik yang dilakukan untuk memperoleh data adalah pengujian tarik ring transversal.

\section{METODOLOGI}

Dalam penelitian ini digunakan pipa SS-304 dengan diameter $30 \mathrm{~mm}$ dipotong berbentuk cincin (ring) seperti yang ditunjukkan pada Gambar 2. Sampel untuk pengujian tarik dibuat dengan lebar $3 \mathrm{~mm}$.
Sampel SS-304 dioksidasi dengan variasi temperatur 600,800 dan $1000{ }^{\circ} \mathrm{C}$ dengan laju pemanasan $5{ }^{\circ} \mathrm{C} /$ menit. Waktu penahanan proses oksidasi tersebut dilakukan selama 1 dan 2 jam. Setelah waktu pemanasan dalam proses oksidasi tercapai, sampel SS304 didinginkan secara alamiah dan dipercepat dengan media pendingin air. Perubahan kekerasan pada permukaan sampel SS-304 diuji dengan menggunakan alat uji kekerasan mikro Vickers dengan pemberian beban sebesar $200 \mathrm{kgf}$ dan waktu kontak selama 10 detik. Pengujian tarik sampel SS-304 dilakukan menggunakan mesin uji tarik Shimadzu AGS-X dengan load cell sebesar $10 \mathrm{kN}$, parameter laju penarikan yang diberikan sebesar $1 \mathrm{~mm} / \mathrm{s}$ dan dilakukan dengan menggunakan pemegang sampel khusus untuk sampel berbentuk cincin.

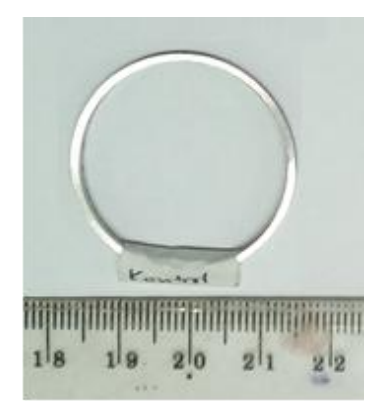

Gambar 2. Sampel SS304 berbentuk cincin

\section{HASIL DAN PEMBAHASAN}

Hasil analisis kekerasan diperoleh nilai kekerasan Vickers sampel SS-304 sebelum dikenai perlakuan oksidasi sebesar 281,25 HV dan nilai ini lebih tinggi dari yang diperoleh oleh peneliti lain[7]. Pengujian dilakukan pada permukaan luar cincin sampel. Perubahan nilai kekesaran sampel SS-304 setelah mengalami oksidasi disajikan pada Gambar 3.

Gambar 3 memperlihatkan bahwa kecenderungan nilai kekerasan permukaan sampel setelah perlakukan oksidasi baik yang didinginkan secara alamiah maupun dipercepat menggunakan air mengalami 
peningkatan dibandingkan nilai kekerasan sebelum dikenai perlakukan oksidasi. Secara umum nilai kekerasan sampel yang dipercepat pendinginannya lebih tinggi dibandingkan dengan kekerasan sampel yang pendinginannya dilakukan secara alamiah. Laju pendinginan yang cepat membuat nilai kekerasan meningkat[8]. Kecenderungan perubahan nilai kekerasan mikro dalam proses oksidasi dengan waktu yang sama terlihat bahwa pada temperatur oksidasi $800{ }^{\circ} \mathrm{C}$ lebih rendah dibandingkan kekerasan pada temperatur oksidasi $600{ }^{\circ} \mathrm{C}$ dan $1000^{\circ} \mathrm{C}$.

Pada temperatur oksidasi $600{ }^{\circ} \mathrm{C}$, sampel SS304 mengalami fasa alpha' perubahan martensit dengan waktu proses selama 1 jam. Pada saat penggunaan kondisi pendinginan secara alamiah terjadi perubahan yang cenderung ke arah fasa alpha yang berasal dari perubahan martensit saja. Perubahan fasa yang terjadi ketika waktu proses selama 2 jam dengan kondisi pendinginan alamiah memiliki mekanisme yang berbeda. Mekanisme yang terjadi adalah pembentukan fasa alpha, perubahan martensit dan juga terjadi rekristalisasi $[8,9]$. Hal ini yang menyebabkan kekerasan sampel SS304 yang diproses dengan waktu selama 2 jam lebih tinggi dibandingkan yang diproses selama 1 jam.

Kondisi proses oksidasi yang dilakukan pada temperatur $800^{\circ} \mathrm{C}$ selama 1 jam dengan proses pendinginan alamiah nilai kekerasan permukaanya turun menjadi $273 \mathrm{HV}$, dimana nilai ini $3 \%$ lebih rendah dibandingkan nilai kekerasan sebelum dikenai proses oksidasi. Sampel SS304 yang merupakan baja tahan karat austenite, dalam hal ini akan mengalami deformasi dislokasi selama proses pemanasan terjadi. Semakin tinggi temperatur dan semakin lama waktu pemanasan berakibat terjadinya proses dislokasi. Kondisi yang terjadi saat pemanasan pada temperatur $800{ }^{\circ} \mathrm{C}$ selama 1 jam dengan pendinginan alamiah seperti yang terlihat pada Gambar 3 adalah terjadinya rekristalisasi statik dimana jumlah dislokasi mengalami penurunan sehingga tegangan internal akan berkurang dan logam akan melunak yang ditunjukkan dengan penurunan nilai kekerasannya. Proses rekristalisasi ini memungkinkan terjadi pelunakan sampai kekerasanya lebih rendah dibandingkan dengan sebelum dikenai proses pemanasan. Keseluruhan nilai kekerasan sampel setelah dikenai proses oksidasi lebih tinggi dibandingkan dengan hasil yang diperoleh peneliti lain[7].

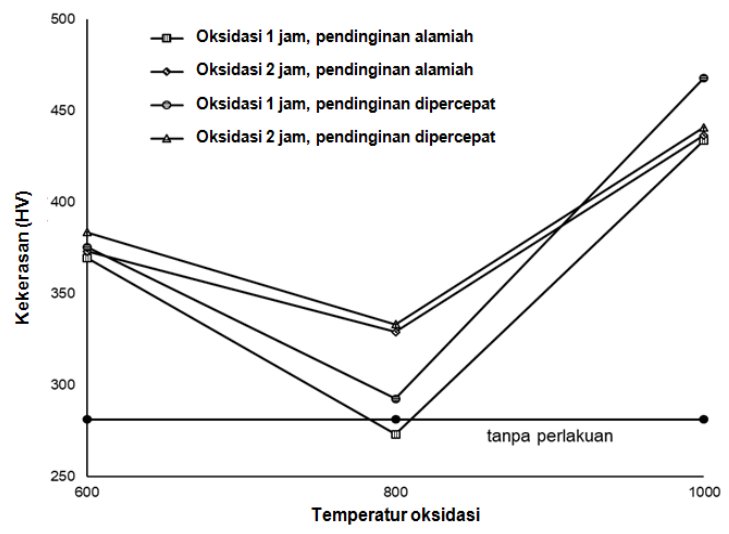

Gambar 3. Perubahan kekerasan SS304 dengan pendinginan alamiah dan pendinginan cepat.

Pada Gambar 3 terlihat bahwa pemanasan temperatur oksidasi $1000{ }^{\circ} \mathrm{C}$ selama 1 jam berada pada daerah rekristalisasi dan sangat dekat dengan daerah metal carbide (MC). Pemanasan pada temperatur oksidasi $1000{ }^{\circ} \mathrm{C}$ selama 2 jam berada pada daerah MC. Proses pendinginan dipercepat menggunakan air setelah proses pemanasan selesai dapat mempertahankan fasa saat proses pemanasan selesai.

Proses oksidasi sampel SS304 pada temperatur $1000{ }^{\circ} \mathrm{C}$ selama 1 jam, tegangan internal akan meningkat dengan terjadinya dislokasi yang semakin tinggi. Peningkatan diikuti dengan peningkatan nilai kekerasannya hingga mencapai sebesar 468 HV. Waktu proses oksidasi selama 2 jam, terbentuk fasa MC yang kekerasannya tidak lebih tinggi dari proses dengan waktu selama 1 jam. Hal ini dikarenakan pada saat 
terbentuk fasa $M C$, unsur karbon juga bereaksi dengan unsur oksigen membentuk karbon oksida. Terbentuknya karbon oksida membuat konsentrasi karbon di dalam baja berkurang (de-carburizing) [11]. Proses decarburizing memberikan pengaruh terhadap penurunan nilai kekerasan permukaannya.

Nilai strength pengujian tarik sampel SS304 disajikan pada Gambar 4. Nilai YS dan UTS bahan SS304 sebelum dikenai perlakukan oksidasi diperoleh masingmasing sebesar 534,29 $\mathrm{MPa}$ dan 689,41 $\mathrm{MPa}$. Perubahan nilai YS dan UTS kecenderungan menurun seiring dengan

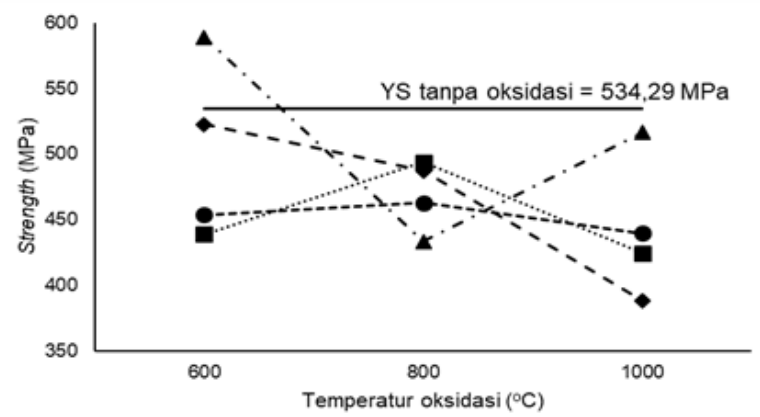

(a) peningkatan temperatur oksidasi. Hal ini menunjukkan bahwa perlakuan pendinginan mempengaruhi karakterstik mekanik sampel SS304 yang dikenai oksidasi melalui perubahan fasa.

Perubahan nilai UTS terjadi dengan kecenderungan yang berbeda terlihat pada sampel SS304 yang dioksidasi selama 2 jam dengan pendinginan alamiah. Nilai UTS jauh lebih tinggi pada sampel SS304 yang dioksidasi pada temperatur oksidasi $600{ }^{\circ} \mathrm{C}$ dibandingkan dengan temperatur oksidasi 800 dan $1000^{\circ} \mathrm{C}$.

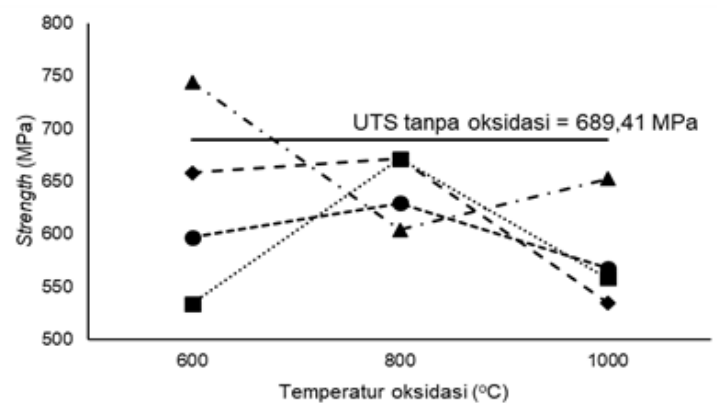

(b)

Keterangan: $\cdots \cdots$ oksidasi 1 jam, pendinginan alamiah

- ^- oksidasi 2 jam, pendinginan alamiah

- - oksidasi 1 jam, pendinginan dipercepat

--•--oksidasi 2 jam, pendinginan dipercepat

Gambar 4. Korelasi perlakuan oksidasi SS304 terhadap nilai (a) YS dan (b) UTS.

Persentase perubahan elongasi pada sampel yang diberi perlakuan oksidasi dibandingkan terhadap sampel tanpa perlakukan oksidasi disajikan pada Tabel 2.

Tabel 2. Perubahan elongasi sampel SS304 yang dikenai perlakuan oksidasi terhadap sampel tanpa perlakuan.

\begin{tabular}{|l|c|c|c|}
\hline \multirow{2}{*}{ Waktu oksidasi/pendinginan } & \multicolumn{3}{|c|}{ Temperatur $\left({ }^{\circ} \mathrm{C}\right)$} \\
\cline { 2 - 4 } & 600 & 800 & 1000 \\
\hline 1 jam/ alamiah & $-7,54 \%$ & $12,94 \%$ & $-4,05 \%$ \\
\hline 2 jam/ alamiah & $12,38 \%$ & $17,50 \%$ & $3,41 \%$ \\
\hline 1 jam/ dipercepat & $-8,18 \%$ & $11,02 \%$ & $16,22 \%$ \\
\hline 2 jam/ dipercepat & $-11,10 \%$ & $12,94 \%$ & $-11,24 \%$ \\
\hline
\end{tabular}

Tabel 2 menunjukkan bahwa pada beberapa temperatur proses oksidasi terlihat terjadi penurunan nilai elongasi (ditandai nilai minus). Hal ini menunjukkan bahwa sampel SS304 pada kondisi proses oksidasi tersebut meningkatkan kegetasan. Proses oksidasi pada temperatur $800{ }^{\circ} \mathrm{C}$ membuat keseluruhan sampel SS304 menjadi lebih daktil. Perubahan elongasi yang tertinggi sebesar $17,50 \%$ pada waktu oksidasi selama 2 jam dengan pendinginan alamiah, sedangkan proses oksidasi pada $1000{ }^{\circ} \mathrm{C}$ 
selama 2 jam dengan pendinginan dipercepat membuat sampel SS304 kegetasannya meningkat karena diperoleh perubahan elongsinya sebesar $-11,24 \%$. Pada temperatur oksidasi sebesar $600{ }^{\circ} \mathrm{C}$ selama 2 jam dengan proses pendinginan dipercepat menunjukkan kekuatan luluh meningkat ketika perubahan elongasi yang rendah sebesar $-11,10 \%$, dimana kondisi ini dapat disimulasikan dengan baik oleh peneliti lain [12].

Karakteristik daktil sampel SS304

dilihat secara komprehensif dari nilai kekerasan, UTS dan perubahan elongasi yang menunjukkan adanya perubahan elongasi tertinggi pada proses oksidasi 2 jam dengan pendinginan alamiah pada temperatur $600{ }^{\circ} \mathrm{C}$ dan $800{ }^{\circ} \mathrm{C}$ dengan perubahan elongasi positif berturut-turut sebesar $12,38 \%$ dan $17,50 \%$. Nilai UTS berturut-turut sebesar $744,04 \mathrm{MPa}$ dan
604,14 MPa. Kekerasan tertinggi diantara keduanya diperoleh pada temperatur oksidasi $600{ }^{\circ} \mathrm{C}$ dengan nilai kekerasannya berturut-turut sebesar 373 HV dan 329 HV.

Pada temperatur oksidasi $1000{ }^{\circ} \mathrm{C}$ selama 1 jam dengan pendinginan cepat diperoleh kekerasan sebesar 468 HV dan perubahan elongasi positif sebesar 16,22 \%. Nilai UTS sebesar 567,68 MPa lebih rendah dibandingkan dengan yang diproses oksidasi $800{ }^{\circ} \mathrm{C}$ selama 2 jam dengan perlakukan pendinginan alamiah.

Dalam menentukan proses oksidasi yang menghasilkan karakteristik daktil pada sampel,dilakukan analisis matriks keputusan terhadap parameter kekerasan, UTS dan perubahan elongasi. Matriks keputusan tersebut disusun dengan metode skor langsung dan datanya disajikan pada Tabel $3[13]$.

Tabel 3. Matriks keputusan parameter kekerasan, UTS dan perubahan elongasi.

\begin{tabular}{|c|c|c|c|c|c|c|c|c|c|c|c|c|}
\hline \multirow{3}{*}{$\begin{array}{c}\text { Waktu } \\
\text { oksidasi/ } \\
\text { pendinginan }\end{array}$} & \multicolumn{12}{|c|}{ Temperatur $\left({ }^{\circ} \mathrm{C}\right)$} \\
\hline & \multicolumn{4}{|c|}{600} & \multicolumn{4}{|c|}{800} & \multicolumn{4}{|c|}{1000} \\
\hline & Kekerasan & UTS & $\begin{array}{c}\text { Perubahan } \\
\text { elongasi }\end{array}$ & Total & Kekerasan & UTS & $\begin{array}{c}\begin{array}{c}\text { Perubahan } \\
\text { elongasi }\end{array} \\
\end{array}$ & Total & Kekerasan & UTS & $\begin{array}{c}\text { Perubahan } \\
\text { elongasi }\end{array}$ & Total \\
\hline $\begin{array}{c}1 \text { jam/ } \\
\text { alamiah }\end{array}$ & 2 & 1 & 1 & 4 & 1 & 3 & 3 & 7 & 4 & 1 & 1 & 6 \\
\hline $\begin{array}{l}2 \text { jam/ } \\
\text { alamiah }\end{array}$ & 3 & 4 & 3 & 10 & 2 & 2 & 4 & 8 & 4 & 3 & 2 & 9 \\
\hline $\begin{array}{l}1 \text { jam/ } \\
\text { dipercepat }\end{array}$ & 3 & 3 & 1 & 7 & 1 & 3 & 3 & 7 & 4 & 1 & 4 & 9 \\
\hline $\begin{array}{l}2 \text { jam/ } \\
\text { dipercepat }\end{array}$ & 3 & 2 & 1 & 6 & 2 & 2 & 3 & 7 & 4 & 1 & 1 & 6 \\
\hline
\end{tabular}

Nilai terendah diberi bobot 1 dan nilai tertinggi diberi bobot 4 . Dari matriks keputusan ini karakteristik daktil ditentukan dengan nilai total yang tertinggi. Hasil yang diperoleh menunjukkan nilai total tertinggi diperoleh pada sampel yang dioksidasi pada temperatur $600{ }^{\circ} \mathrm{C}$ selama 2 jam dengan pendinginan alamiah. Berturut-turut nilai total tertinggi berikutnya diperoleh sampel yang dioksidasi pada temperatur $1000^{\circ} \mathrm{C}$ selama 2 jam dengan pendinginan alamiah dan selama 1 jam dengan pendinginan dipercepat.

Gambar 5 disajikan moda fraktur sampel SS304 tanpa dikenai proses oksidasi dibandingkan terhadap sampel
SS304 yang dikenai proses oksidasi pada temperatur $600{ }^{\circ} \mathrm{C}$ selama 1 jam baik dengan proses pendinginan alamiah maupun dipercepat.

Gambar 5.a menunjukkan moda fraktur yang terjadi pada sampel SS304 tanpa perlakuan oksidasi. Pada saat sampel ditarik terjadi necking dimana lebar dan ketebalan sampel pada daerah gage akan menurun. Fraktur terjadi dimulai dari sisi yang ditunjuk oleh tanda panah. Selama pengujian tarik deformasi terus terjadi dan retakan mengalami pelebaran (menjalar) hingga ke sisi tepinya. Moda fraktur seperti ini menunjukkan bahan tersebut bersifat daktil. 


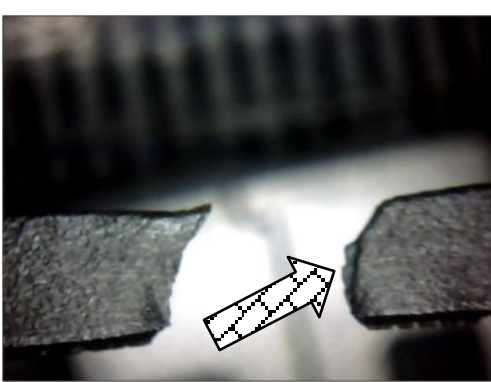

(a)

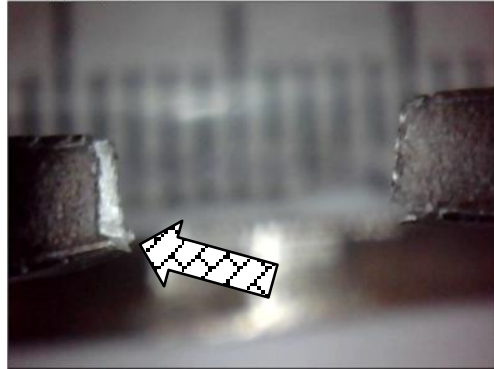

(b)

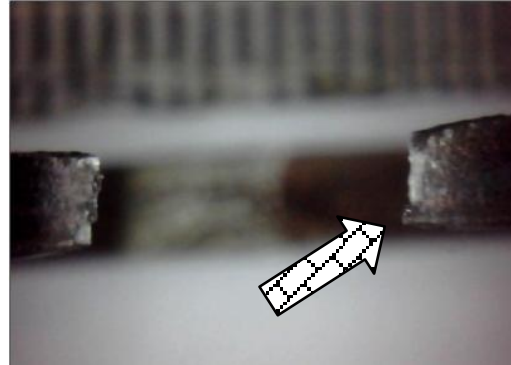

(c)

Gambar 5. Fraktur pada sampel SS304 saat pengujian tarik

(a) tanpa perlakuan oksidasi

(b) oksidasi pada temperatur $600{ }^{\circ} \mathrm{C}$ selama 1 jam dengan pendinginan alamiah

(c) oksidasi pada temperatur $600{ }^{\circ} \mathrm{C}$ selama 1 jam dengan pendinginan dipercepat.

Gambar 5.b dan 5.c menunjukkan hasil yang sedikit berbeda, dimana necking yang terjadi berbeda dengan sampel SS304 yang tidak mengalami proses oksidasi. Hal ini disebabkan karena dislokasi dan tegangan internal yang relatif lebih tinggi pada sampel SS304 membuat moda fraktur yang terjadi serupa dengan patahan pada bahan yang getas dengan karakteristik merata sepanjang lebar sampel SS304. Namun dari bentuk fraktur yang ditunjukkan oleh tanda panah terlihat adanya necking sehingga masih memiliki karakteristik daktil. Perilaku seperti ini juga terjadi untuk sampel yang dikenai perlakukan panas pada temperatur 800 dan $1000^{\circ} \mathrm{C}$.

\section{SIMPULAN}

Proses oksidasi SS304 pada temperatur $600{ }^{\circ} \mathrm{C}, 800{ }^{\circ} \mathrm{C}$ dan $1000{ }^{\circ} \mathrm{C}$ dengan perlakukan pendingin alamiah dan dipercepat menggunakan air mempengaruhi karaktetistik daktilitas bahan. Karakteristik daktilitas dilihat dari parameter kekerasan, perubahan elongasi dan UTS dapat digunakan sebagai pedoman penggunaan sampel SS304 dilingkungan oksidasi pada temperatur tinggi. Daktilitas, kekerasan dan UTS relatif tinggi diperoleh pada temperatur $600{ }^{\circ} \mathrm{C}$ selama 2 jam dengan perlakuan pendinginan alamiah. Hasil karakterisasi SS304 dalam lingkungan oksidasi menunjukkan bahwa sebaiknya temperatur maksimum tidak lebih besar dari $600^{\circ} \mathrm{C}$.

\section{UCAPAN TERIMA KASIH}

Ucapan terima kasih disampaikan kepada Ka.PTBBN dan penanggung jawab kegiatan "Pengembangan Metode Baku Uji Pasca Iradiasi Bahan Struktur Elemen Bakar Reaktor Daya" yang dibiayai oleh DIPA 2017. Selain itu, ucapan terima kasih juga disampaikan kepada Isfandi, Dedi Hariyadi, dan Triharjo atas bantuan yang diberikan sehingga kegiatan ini dapat terlaksana.

\section{DAFTAR PUSTAKA}

[1] A. Renault, J. Malaplate, C. Pokor, P. Gavoille, "TEM and EFTEM characterization of solution annealed 304L stainless steel irradiated in PHENIX, up to $36 \mathrm{dpa}$ and at $390{ }^{\circ} \mathrm{C}, "$ Journal of Nuclear Materials, vol.421, no. 1-3, pp. 124-131, 2012.

DOI: 10.1016/j.jnucmat.2011.10.049

[2] C. Azevedo, "Selection of fuel cladding material for nuclear fission reactors." Engineering Failure Analysis, vol.18, no. 8, pp. 1943-1962, 2011.

DOI: 10.1016/j.engfailanal.2011.06.010

[3] R. Plaut, C. Herrera, D. Escriba, P. Rios and A. Padilha, "A short review on wrought austenitic stainless steels at 
high temperatures: processing, microstructure, properties and performance," Materials Research, vol. 10, no. 4, pp. 453-460, 2007. DOI:10.1590/1516-1439.2007.00040

[4] M. Sharma and A. Kumar, "Study of effect on mechanical properties of SS 304 at different ranges of carburization temperature," IJCSCE, Special issue on NCRAET 2013, pp. 13-17.

[5] F. K. Yan, G. Z. Liu, N. R. Tao, and K. $\mathrm{Lu}$, "Strength and ductility of $316 \mathrm{~L}$ austenitic stainless steel strengthened by nano-scale twin bundles," Acta Materialia, vol. 60, no. 3, pp. 10591071, 2012.

DOI: 10.1016/j.actamat.2011.11.009

[6] M. Calmunger, "High-temperature behaviour of austenitic alloys : Influence of temperature and strain rate on mechanical properties and microstructural development," Thesis, Linköping University, 2013.

[7] D. Samantaray, V. Kumar, A. K. Bhaduri, and P. Dutta, "Microstructural evolution and mechanical properties of type $304 \mathrm{~L}$ stainless steel processed in semi-solid state," International Journal of Metallurgical Engineering, vol. 2, no. 2, pp. 149-153, 2013.

DOI: 10.5923/j.ijmee.20130202.06

[8] S. C. Maidargi and V. Rani, "Heat treatment of steel parts in different media," Journal of Metals, Materials and Minerals, vol. 23, no. 2, pp. 1- 7, 2013.

[9] H. M. Farneze, S. S. M.Tavares, J. M. Pardal, A. J. R. Londoño, V. F. Pereira, and C. Barbosa, "Effects of Thermal Aging on Microstructure and Corrosion Resistance of AISI 317L Steel Weld Metal in the FSW Process," Materials Research, vol. 18, pp. 98-103, 2015. DOI: $10.1590 / 1516-1439.345414$

[10] R. A. Behnagh, M. K. Besharati Givi, and M. Akbari. "Mechanical properties, corrosion resistance and microstructural changes during friction stir processing of 5083 aluminum rolled plates," Materials and Manufacturing Processes, vol. 27, no. 6, pp. 636-640, 2012.

DOI: $10.1080 / 10426914.2011 .593243$

[11] W. Liu, "Failure analysis of a fluidisation nozzle in biomass boiler and the longterm high temperatures oxidation behaviour of 304 stainless steel," Engineering Failure Analysis vol. 70, pp. 419-427, 2016.

DOI: 10.1016/j.engfailanal.2016.10.001

[12] V. Vijayaraghavan, A. Garg, K. Tai, and Liang Gao. "Thermo-mechanical modeling of metallic alloys for nuclear engineering applications," Measurement, vol. 97, pp. 242-250, 2017.

DOI:

10.1016/j.measurement.2016.11.003

[13] B. C. Suedel, Jongbum Kim, and Cynthia J. Banks, "Comparison of the Direct Scoring Method and MultiCriteria Decision Analysis for Dredged Material Management Decision Making," No. ERDC-TN-DOER-R13, Engineer Research and Development Center Vicksburg MS Environmental Lab, 2009. 